\title{
Kocatepe Veterinary Journal
}

Kocatepe Vet J (2016) 9(4): 322-326

DOI: $10.5578 / \mathrm{kvj} .35305$

Submittion: 12.10 .2016

RESEARCH ARTICLE

Accepted: 23.11 .2016

\section{Various FSH Administration on Superovulatory Response and Embryo Yield in Anatolian Black Heifers}

\author{
Umut TAŞDEMİR ${ }^{1 *}$,Tahir KARAŞAHİN ${ }^{2}$,Muharrem SATILMIŞ ${ }^{3}$,Sedat Hamdi KIZIL $^{3}$ \\ Mustafa KAYMAZ ${ }^{4}$ \\ 1 Aksaray University, Technical Sciences Vocational School, Aksaray/TÜRKIYYE \\ ${ }^{2}$ Aksaray University, Faculty of Veterinary Medicine, Department of Physiology, Aksaray/TÜRKIYE \\ 3international Livestock Research Institute, Ankara/TÜRKIYYE \\ ${ }^{4}$ Ankara University, Faculty of Veterinary Medicine, Department of Obstetrics and Gynecology, Ankara, /TÜRKIYE
}

Corresponding author e-mail: tasdemiru@gmail.com

\# This study was financed under a project supported by the Scientific and Technological Research Council of Turkey (TUBITAK) (Project No: 106G005, TURKHAYGEN-1).

\begin{abstract}
The aim of the present study was to investigate effectiveness of superovulatory response and embryo yield in Anatolian Black heifers, induced with the administration of two different follicle stimulating hormone. Heifers received a progesterone releasing device (Cue-mate containing $1.56 \mathrm{~g}$ progesterone). The heifers were randomly assigned to four groups. Group Folltropin (F) were administered with Folltropin $(400 \mathrm{mg})$ as a control, while those included in Groups Ovagen $(\mathrm{O})$ were administered with Ovagen at doses of $8.8 \mathrm{mg}(\mathrm{O} 1), 11.44 \mathrm{mg}(\mathrm{O} 2)$ and $17.6 \mathrm{mg}(\mathrm{O} 3)$ respectively. On the 9th day of the application, the Cue-mate was removed and the heifers received $500 \mu \mathrm{g}$ prostaglandinF $2 \alpha$ in all goups. The heifers were artificially inseminated (AI) using semen obtained from Anatolian Black bulls; in the evening of day 11 and in the morning of day 12 with 12 hours intervals. Embryos were collected by uterine flushing 7 days after AI. The mean number of CL determined as $6.33 \pm 0.718$ in $\mathrm{F}$, was found to be higher than the numbers obtained with the administration of the three different doses of $\mathrm{O}(3.82 \pm 0.502,3.50 \pm 0.513,3.58 \pm 0.448$ respectively; $\mathrm{p}<0.001)$. The transferable embryo yield did not differ significantly among the treatment groups $(\mathrm{p}>0.05)$. In conclusion, findings show that although the administration of $F$ was ascertained increase the number of CL and the total number of ova/embryos recovered, these increased numbers had no reflection on the number of transferable embryos in Anatolian Black heifers.
\end{abstract}

Key Words: Anatolian Black heifer, Folltropin, FSH, Ovagen, Superovulation

\section{Yerli Kara Düvelerde Süperovulasyon ve Embriyo Verimi Üzerine Farklı FSH Uygulamalarının Etkileri}

\section{ÖZ}

Bu çalışmanın amacı Yerli Kara düvelerde süperovulasyon oluşturma ve embriyo elde etme yönünde iki farklı follikül uyarıcı hormonunun etkinliğini gözlemlemekti. Düvelere $1.56 \mathrm{~g}$ progesteron içeren Cue-mate uygulandı. Düveler dört gruba ayrıldı. Folltropin (F) grubuna control olarak $400 \mathrm{mg}$ folltropin diğer taraftan Ovagen (O) grubuna ise sirasiyla $8.8 \mathrm{mg}(\mathrm{O} 1), 11.4$ (O2) ve 17.6 (O3) olmak üzere Ovagen uyguland1. Süperovulasyon protokolünün 9. gününde Cue-mate ç1karıld1 ve gruplardaki tüm ineklere $500 \mu \mathrm{g}$ prostaglandinF2 $\alpha$ yapıldı. 11. gün akşam ve 12. gün sabah olmak üzere 12 saat ara ile tüm ineklere Yerli Kara boğalardan alınan spermalar ile suni tohumlama yapıldı. Suni tohumlama uygulamasından 7 gün sonra embriyo elde etme çalışması ile embriyolar toplandı. Ortalama CL sayıları F grubunda $6.33 \pm 0.718$ belirlenirken, O grubunda uygulanan üç farklı dozdan (sırasiyla $3.82 \pm 0.502,3.50 \pm 0.513,3.58 \pm 0.448 ; \mathrm{p}<0.001$ ) elde edilen CL sayılarından daha yüksek bulundu. Transfer edilebilir embriyo oranları uygulama grupları arasında farklı değildi ( $p>0.05$ ). Sonuç olarak, bulgular $F$ grubunda yapılan uygulamanın CL, elde edilen embriyo ve ovum sayısını artırmasına rağmen transfer edilebilir embriyo sayısına olumlu bir etkisinin olmadığını gösterdi.

Anahtar Kelimeler: Yerli Kara Düve, Folltropin, FSH, Ovagen, Süperovulasyon.

To cite this article: Taşdemir U, Karaşahin T, Satılmış M, Kız1 SH, Kaymaz M.Various FSH Administration on Superovulatory Response and Embryo Yield in Anatolian Black Heifers. Kocatepe Vet J. 2016; 9(4): 322-326. 


\section{INTRODUCTION}

Animal genetic resources are an integral element of biodiversity. Indigenous animal breeds have adaptation adverse environmental impact. The Anatolian Black, which is indigenous cattle breed characterised by delayed puberty, has well adapted to the severe climatic conditions of Anatolia and is commonly raised at high altitudes in Turkey (Compan and Cividini 2008). The genetic material of this particular breed needs to be preserved, by reason of the pure Anatolian Black cow population has dramatically decreased, particularly in the last decade (Taşdemir et al. 2012). Embryo transfer that has been applied all over the world is a suitable method for preservation of endangered animal species and breeds (Wildt et al. 19912, Solti et al. 2000). Besides, this method is used to increase the number of offspring obtained from donors with high genetic value (Baruselli et al. 2006) and it significantly reduces the time period required for genetic improvement and offers several advantages in comparison to natural breeding programme (Barati et al. 2006). There are various protocols applied for superovulation, which produce embryos (Silva et al. 2009). It is reported that, 5 to 6 transferable embryos have been obtained each superovulation treatment in the Bos taurus (Hasler 1992). It is well known the quality of the embryo obtained from donor cattle is influenced by both intrinsic and extrinsic factors. Intrinsic factors include genetics, individual sensitivity to gonadotropins, age, nutritional and health status (Silva et al. 2009). As for that extrinsic factors include the use of different commercial FSH preparations, dosage, season and administration route (Kafi and McGowan 1997, Taşdemir et al. 2012). There are many reports on the efficiency of FSH treatment for ovarian superstimulatory response in the cow. However, there are few studies that provide knowledge on superovulatory response and embryo yield in indigenous breed heifers. Therefore, the aim of present study was to investigate effectiveness of superovulatory response and embryo yield in Anatolian Black heifers, induced with the administration of various doses of two different follicle stimulating hormone.

\section{MATERIALS and METHODS}

\section{Animals}

Twenty-one heifers (Bos Taurus) aged 2-4 years and of a mean body weight of 250-300 kg, which were housed out doors in a sheltered pen, constituted the material of the study. The heifers were fed three times a day with concentrated feed together with high quality alfalfa hay and barley straw. Water was supplied ad libitum. The same heifers were used in each group with crossover design. All heifers were palpated per rectum prior to the study to determine possible reproductive tract abnormalities. The experimental procedures were approved by the Animal Care Committee of Istanbul University, Faculty of Veterinary Medicine.

\section{Study design}

Anatolian Black heifers received a progesterone releasing device (Cuemate-1.56 g progesterone, Bioniche Animal Health Ltd, New Zeland) on a random day of cycle (day 0). The heifers were divided into four groups based on the dose of Folttropin (F) (400 mg NIH-FSH-P1, Bioniche Animal Health Inc., Ontario, Canada) and Ovagen (O) (17.6 mg NIADDK-oFSH- 17 standart, Immuno-Chemical Products Ltd. Auckland, New Zeland). In group F a total of $400 \mathrm{mg}$ FSH was given as intramuscular (im) injection in decreasing doses twice daily for 4 days $(80,80,60,60,40,40,20,20$ $\mathrm{mg} ; \mathrm{n}=21)$. In group $\mathrm{O} 1, \mathrm{O} 2$ and $\mathrm{O} 3$ a total of 8.8 , 11.44 and $17.6 \mathrm{mg}$ Ovagen were given as im injection in decreasing doses twice a daily for 4 days $(1.76,1,32,1.32,0.88,0.88,0.88,0.88,0.88 \mathrm{mg}$ in group O1; 2.10, 1.66, 1.66, 1.32, 1.32, 1.32, $0.88,0.88$ in group $\mathrm{O} 2 ; 3.52,3.52,2.64,2.64,1.76,1.76,0.88$, 0.88 in group $\mathrm{O} 3$ respectively; $\mathrm{n}=21$ ). In all groups superovulatory treatments were initiated on day 7 of the cycle. nine days later begining of the cycle, the Cue-mate was removed and heifers received $500 \mu \mathrm{g}$ prostaglandinF2 $\alpha$ (PGF2 $\alpha$; Cloprostenol, $500 \mu \mathrm{g}$, im, Estrumate ${ }^{\circledR}$, Intervet, Turkey). The heifers were artificially inseminated twice using semen obtained from Anatolian Black bulls; in the evening of day 11 and in the morning of day 12 with 12 hours intervals. Ovaries were checked at the begining of flushing to determine number of CL by ultrasonographic examinations (Falco 100, Pie- Medical- USA). Superovulated heifers were flushed at day 7 after AI. Each heifer was given epidural anaesthesia using 60 mg Adocain (Lidokain HCL, 20mg/ml, Sanovel, Turkey) prior to flushing. The vulva was scrubbed with disinfectant and Foley catheter (13-14 Agtech, USA) with a $15 \mathrm{ml}$ bulb, inserted through the vagina and the cervix. A stainless steel stylet was used to stiffen the catheter to allow passage through the cervix and both horns were flushed with flushing media $(990 \mathrm{ml}$ ringer lactate $+10 \mathrm{ml}$ calf serum $+1 \mathrm{ml}$ kanamycin sulphat) using folley cathater inserted next to the utero-tubal junction. The uterine horns were massaged and manipulated to facilitate medium return flow. The uterine exposed flushing media was collected into $1000 \mathrm{ml}$ sterilized bottle. Collected media was filtered using 0.22 micrometer filter. A stereomicroscope (Olympus, SZH10, Olympus, Japan) was used for searching the embryos. Embryos were morphologically evaluated and classified same person according to the criteria recommended by the IETS (Stringfellow and Seidel 1998). Embryos 
classified as Grade 1 (excellent or good) and 2 (fair) were considered as transferable embryos, while embryos classified as Grade 3 (poor) and 4 (dead or degenerated) were considered as untransferable embryos.

\section{Statistical analysis}

Statistical analyses were made using the MINITAB (MINITAB Release 13.0; Copyright 2000) statistical software. This study provides informative statistical data on the parameters investigated. A square root transformation was performed before the groups were compared for the number of CL by analysis of variance (Proc GLM). Multiple comparisons were made using Tukey's test was performed for the comparison of the groups for embryo recovery rates (RR) and embryo yields.

\section{RESULTS}

As shown table 1 , the mean number of $\mathrm{CL}$ determined as $6.33 \pm 0.718$ in group $\mathrm{F}$, was found to be higher than the numbers obtained with the administration of the three different doses of $\mathrm{O}$ $(\mathrm{P}<0.001)$. In the current study, the transferable embryo yield did not differ significantly among treatment groups $(\mathrm{P}>0.05)$ and were determined as $33.3 \%(13 / 39)$ in the $\mathrm{F}, 40.0 \%(4 / 10)$ in the O1, $69.2 \%(9 / 13)$ in the $\mathrm{O} 2$ and $34.6 \%(9 / 26)$ in the $\mathrm{O} 3$.

Ovum-embryo recovery rate was greater in $\mathrm{F}$ group than the rates obtained with the administration of the three different doses of $\mathrm{O}(\mathrm{p}<0.001)$.

Table 1: The effects of FSH administration on ovarian response and embryo yield

Tablo 1: Süperovulasyon ve embriyo verimi üzerine farklı FSH uygulamasinın etkileri

\begin{tabular}{|c|c|c|c|c|c|}
\hline & Group F & $\begin{array}{c}\text { Group } \\
\text { O1 }\end{array}$ & $\begin{array}{c}\text { Group } \\
\text { O2 }\end{array}$ & $\begin{array}{c}\text { Group } \\
\text { O3 }\end{array}$ & $\mathrm{P}$ \\
\hline $\begin{array}{l}\text { CL } \\
\text { number }\end{array}$ & $\begin{array}{c}6.33 \pm 0.718 \\
\text { a }\end{array}$ & $\begin{array}{c}3.82 \pm 0.5 \\
02^{\mathrm{b}}\end{array}$ & $\begin{array}{c}3.50 \pm 0.5 \\
13^{\mathrm{b}}\end{array}$ & $\begin{array}{c}3.58 \pm 0.4 \\
48^{\mathrm{b}}\end{array}$ & $\begin{array}{c}0.0 \\
01\end{array}$ \\
\hline $\begin{array}{c}\text { Transferab } \\
\text { le embryo } \\
\text { yield }\end{array}$ & $\begin{array}{c}33.3 \% \\
(13 / 39)\end{array}$ & $\begin{array}{l}40.0 \% \\
(4 / 10)\end{array}$ & $\begin{array}{l}69.2 \% \\
(9 / 13)\end{array}$ & $\begin{array}{l}34.6 \% \\
(9 / 26)\end{array}$ & $\begin{array}{l}0.1 \\
29\end{array}$ \\
\hline $\begin{array}{c}\text { Untransfer } \\
\text { able } \\
\text { embryo } \\
\text { yield }\end{array}$ & $\begin{array}{c}66.7 \% \\
(26 / 39)\end{array}$ & $\begin{array}{l}60.0 \% \\
(6 / 10)\end{array}$ & $\begin{array}{l}30.8 \% \\
(4 / 13)\end{array}$ & $\begin{array}{c}65.4 \% \\
(17 / 26)\end{array}$ & $\begin{array}{c}0.1 \\
29\end{array}$ \\
\hline $\begin{array}{l}\text { Recovey } \\
\text { rate }\end{array}$ & $\begin{array}{c}83.5(111 / 1 \\
33)^{\mathrm{a}}\end{array}$ & $\begin{array}{c}41.5(27 / \\
65)^{\mathrm{b}}\end{array}$ & $\begin{array}{c}47.6(30 / \\
63)^{\mathrm{b}}\end{array}$ & $\begin{array}{c}51.5(35 / \\
68)^{\mathrm{b}}\end{array}$ & $\begin{array}{c}0.0 \\
00\end{array}$ \\
\hline $\begin{array}{l}\text { a,b:Diffe } \\
\text { significa }\end{array}$ & it letter & within & the & le line & are \\
\hline
\end{tabular}

\section{DISCUSSION}

The superovulation process is affected by several factors in cattle. One of the main factors which limit embryo production is the effect of gonadotropins, used commercially for superovulation, on the ovaries and these hormones enabling the ovulation of an adequate number of oocytes (Kelly et al. 1997). Granulosa cells possess a limited number of FSH receptors, which activate the growth and development of follicles. When used at favourable level for superovulation purposes, FSH binds to these receptors and produces a satisfactory induction (Gonzales et al. 1990, Hockley et al. 1992). Some authors reported the variability of the ovarian response to superovulation treatments being related to gonadotropin administration route, total dose, timing, LH residue on FSH, duration and the use of additional hormones (Mapletoft et al. 2002, Taşdemir et al. 2011). The current results related to $\mathrm{CL}$ number, in contrast to previous findings in which obtained similar superovulation results with the use of $\mathrm{O}$ and FSH-P in Nelore cattle (Silve at al. 2009). In a study (Nilchuen et al. 2012) in which 200 and $250 \mathrm{mg}$ of FSH (NIH-FSH-P1) did not induce different superovulatory responses in cows and heifers too. Ağaoğlu et al. (2012) suggested that O had a stronger effect on superovulation in Karayaka sheep, compared to that of F. Besides, present results are different to the report obtained from Anatolian Black cow study in which the administration of high and low doses of FSH elicit similar effects on superovulatory response (Taşdemir et al. 2012). On the other hand, the current results obtained in the present study are similar to those reported by some researcher (Carvalho et al. 2013). It was observed that, the administration of $\mathrm{O}$, which contains ovine FSH, had less effect on the superovulatory response, in comparison to $\mathrm{F}$, which contains porcine FSH. The results obtained generate that, porcine FSH was more effective than ovine FSH on the superovulatory response in Anatolian Black heifers. The differences observed in the present study, in comparison to those reported in previous research, were attributed to the genetic differences of Anatolian Black heifer and $\mathrm{O}$ containing a lower quantity of FSH, when compared to F.

Gonadotropins, which contain a high level of LH, adversely affect fertilization rate and embryo quality, gonadotropins containing low levels of $\mathrm{LH}$ are preferred to be used (Herrler et al. 1991, Hockley et al. 1992). F and O have different bioactive FSH and $\mathrm{LH}$ composition; the FSH content of $\mathrm{O}$ is more active compared to that of F (McNatty et al. 1989). In the present study, transferable embryo with the administration of both $\mathrm{F}$ and $\mathrm{O}$ in the Anatolian Black heifers, were lower than those previously reported to have been obtained in local cattle breeds (Baruselli et al. 2006, Silva et al. 2009). However, transferable and non-transferable embryos were found to be similar to those obtained in previous research (Barati et al. 2006, Nichuen et al. 2012). Silva et al. (2009) reported that the transferable embryo obtained with the use of different FSH 
preparations in Nelore cattle did not differ from each other. Similar to our results, in a previous study which Bonsmara cows and heifers were administered with the respective doses of $320 \mathrm{mg}$ and $200-260 \mathrm{mg}$ of NIH-FSH-P1 Folltropin-V, the number of transferable embryos recovered was $5.1 \pm 0.9$ in the cows and $3.7 \pm 0.8$ in the heifers (Carballo et al. 2008). In a study on Mertolenga cattle, informed no difference was determined between Folltropin and FSH-P administration for embryo production with respect to the number of total ovum and embryos (Quaresma et al. 2003). On the contrary to the findings of this study, Ağaoğlu et al. (2012) reported that embryo quality was affected by the type of FSH preparation which had been used for superovulatory stimulation on Karayaka ewes. Based on the current results, difference between the findings may be related to species, genetic differences or poor reproductive performance of Anatolian Black heifer. The ovum-embryo recovery rate determined in the present study was lower than previously reported in the same breed cattle (Taşdemir et al. 2012). Studies on embryos/ova recovery rate (per ovulated follicle) using nonsurgical embryo recovery varied widely from as high as $60-80 \%(11,23)$ to as low as $20-$ $25 \%$ (Ireland et al. 2007). Recovery rate found in this study was consistent with the previously reported acceptable rate. However, in the present study, the ovum-embryo recovery rate achieved with the administration of $\mathrm{F}$ was higher than the rates obtained with the administration of the three different doses of $\mathrm{O}$. It is thought that, as also highlighted by Kanagawa et al. (1995), this difference may be related to several factors, including the experience of the staff performing the treatment, and the timing of collection. The birth canal of Anatolian Black heifer being narrow, complicates the performance of both rectal palpation and embryo collection procedures, and may be responsible for lower embryo recovery rates.

In conclusion, findings show that although the administration of $\mathrm{F}$ was ascertained increase the number of CL and the total number of ova/embryos recovered, these increased numbers had no reflection on the number of transferable embryos in Anatolian Black heifers. It is suggested that $\mathrm{O}$ can be used instead of $\mathrm{F}$ since the required dose for superovulation is less without affecting the transferable embryo yield in indigenous breed.

\section{REFERENCES}

Ağaoğlu AR, Kaymaz M, Ağaoğlu OK, Karakaş $\mathbf{K}$, Yağcı İP, Taşdemir U. Effect of different gonadotropin preparation on ovulatory response and embryo yield in Karayaka Ewes. Kafkas Univ. Vet. Fak. Derg. 2012; 18: 861-864.
Barati F, Niasari-Naslaji A, Bolourchi M, Sarhaddi F, Razavi K, Naghzali E, Thatcher WW. Superovulatory response of Sistani cattle to three different doses of FSH during winter and summer. Theriogenology. 2006; 66: 1149-1155.

Baruselli PS, Sa Filho MF, Martins CM, Nasser LF, Nogueria MFG, Barros CM, Bo GA. Superovulation and embryo transfer in Bos indicus cattle. Theriogenology. 2006; 65: 77 88.

Carballo GD, Tribulo A, Tribulo R, Tríbulo H, Bo GA. Superovulation in the first follicular wave without the use of estradiol in bonsmara cattle. Reprod. Fertil. Dev. 2008; 20: 226.

Carvalho BC, Varago FC, Ruas JRM, Vargas MW, Santos GB, Silva AM. Embryo production in zebu cows after superovulation with two commercial formulations of gonadotropin. R. Bras. Ci. Vet. 2013; 20: 155 159.

Compan D, Cividini A. Editors. Brachycerous cattle in Balkan countries and their perspectives. ERFP Press, Domzale, 2008; pp. 44-46.

Gonzalez A, Lussier JG, Camtthers TD, Murphy BD, Mapletoft RJ. Superovulation of beef heifers with Folltropin: a new preparation containing reduced $\mathrm{LH}$ activity. Theriogenology. 1990; 33: 519-529.

Hasler JF. Current status and potential of embryo transfer and reproductive technology in dairy cattle. J. Dairy Sci. 1992; 75: 2857-2879.

Herrler A, Elsaesser F, Parvizi N, Niemann H. Superovulation of dairy cows with purified FSH supplemented with defined amounts of LH. Theriogenology. 1991; 35: 633-643.

Hockley DK, Bo GA, Palasz AT, Del Campo MR, Mapletoft RJ. Superovulation with a single subcutaneous injection of Folltropin in cow: Effect of dose and site of injection. Theriogenology. 1992; 37: 224.

Ireland JJ, Ward F, Jimenez-Krassel F, Ireland JL, Smith GW, Lonergan P, Evans AC. Follicle numbers are highly repeatable within individual animals but are inversely correlated with FSH concentrations and the proportion of good-quality embryos after ovarian stimulation in cattle. Human Reprod. 2007; 22: 1687-1695.

Kafi M, McGowan MR. Factors associated with variation in the superovulatory response of cattle. Anim. Reprod. Sci. 1997; 48: 137-157.

Kanagawa H, Shimohira I, Saitoh N. Manual of Bovine Embryo Transfer. Japan Livestock Technology Association, Tokyo, 1995; pp. 285 
Kelly P, Duffy P, Roche JF, Boland MP. Superovulation in cattle: effect of FSH type and method of administration on follicular growth, ovulatory response and endocrine patterns. Anim. Reprod. Sci. 1997; 46: 1-14.

Kim IH, Son DS, Yeon SH, Choi SW, Park SB, Ryu IS. Effect of dominant follicle removal before superstimulation on follicular growth, ovulation and embryo production in Holstein cows. Theriogenology. 2001; 55: 937-945.

Mapletoft RJ, Steward KB, Adams GP. Recent advances in the superovulation in cattle. Reprod. Nutr. Dev. 2002; 42: 601-611.

McNatty KP, Hudson NL, Ball K, Mason A, Simmons MH. Super-ovulation and embryo recovery in goats treated with Ovagen and Folltropin. New Z. Vet. J. 1989; 37: 27-29.

Nilchuen P, Chomchai S, Rattanatabtimtong S. Superovulation with different doses of follicle stimulating hormone in Kamphaeng Saen beef cattle. J. Anim. Vet. Adv. 2012; 11 (5): 676680.

Quaresma MA, Costa LL, Silva JR. Superovulation of Mertolenga cows with two FSH preparations (FSH-P and FOLLTROPIN). Rev. Port. Ci. Vet. 2003; 98: 81-84.

Silva JCC, Alvarez RH, Zanenga CA, Pereira GT. Factors affecting embryo production in superovulated Nelore cattle. Anim. Reprod. 2009; 6: 440-445.

Solti L, Crichton EG, Loskutoff NM, Cseh S. Economical and ecological importance of indigenous livestock and application of assisted reproduction to their preservation. Theriogenology. 2000; 53: 149-162.

Stringfellow DA, Seidel GE. Editors. Photographic illustration of embryo developmental stage and quality codes. 3. Ed. Savoy, Manuel of International Embryo Transfer Society, IL, IETS. 1998.

Taşdemir U, Ağaoğlu AR, Kaymaz M, Karakaş $\mathbf{K}$. Ovarian response and embryo yield of Angora and Kilis goats given the Day 0 Protocol for superovulation in the nonbreeding season. Trop. Anim. Health Prod. 2011; 43: 1035-1038.

Taşdemir U, Satılmış M, Karaşahin T, Kızıl SH, Kaymaz M, Imai K. The effect of single epidural

plus intramusculer injection of FSH on superovulatory response in Anatolian Black cow. Ank. Univ. Vet. Fak. Derg. 2012; 59: 211-216.

Wildt DE, Monfort ST, Donoghue AM, Johnston LA, Howard J. Embryogenesis in conservative biology or, how to make an endangered species embryo. Theriogenology. 1992; 37: 161-184. 